by Heejung Kim ${ }^{1}$, Jin-Yong Lee ${ }^{2}$, Stanley Finney ${ }^{3}$, Giuseppe Di Capua ${ }^{4}$, Gurmeet Kaur ${ }^{5}$, and Maria Dolores Pereira ${ }^{6 *}$

\title{
Universal value to be pursued in Episodes
}

\author{
${ }^{1}$ Managing Editor of Episodes, Department of Geology, Kangwon National University, Chuncheon 24341, Republic of Korea \\ ${ }^{2}$ Editor in Chief of Episodes, Department of Geology, Kangwon National University, Chuncheon 24341, Republic of Korea \\ ${ }^{3}$ IUGS Secretary General, Department of Geological Sciences, California State University, Long Beach, CA 90840 \\ ${ }^{4}$ IUGS Publications Committee member, Istituto Nazionale di Geofisica e Vulcanologia, Italy \\ ${ }^{5}$ IUGS Publications Committee member, Department of Geology, Panjab University, Chandigarh-160014, India \\ ${ }^{6}$ IUGS Publications Committee Chair, Department of Geology, University of Salamanca, 37008 Salamanca, Spain; \\ *Corresponding author,*E-mail: mdp@usal.es
}

(Received: April 24, 2021; Revised accepted: May 14, 2021)

https://doi.org/10.18814/epiiugs/2021/021007

\section{Open Access}

The Budapest Open Access Initiative (BOAI) declared on February 14, 2002, that "By "open access" to [peer-reviewed research literature], we mean its free availability on the public internet, permitting any users to read, download, copy, distribute, print, search, or link to the full texts of these articles, crawl them for indexing, pass them as data to software, or use them for any other lawful purpose, without financial, legal, or technical barriers other than those inseparable from gaining access to the internet itself. The only constraint on reproduction and distribution, and the only role for copyright in this domain, should be to give authors control over the integrity of their work and the right to be properly acknowledged and cited." (BOAI, 2002, 2012; Suber, 2012).

"Open access" means anyone can access and use academic information on the Internet without barriers. It is a new way to distribute academic information that breaks with the convention whereby the distribution of academic information is centered on academic journals and publishers. Open access is based on the philosophy of sharing knowledge and remedying difficulties in distributing high-quality information and knowledge due to cost issues. Although existing subscription-based models incur costs at the output stage, open access provides economic benefits to individual subscribers and institutions accessing academic information and published works by applying a model whereby the author voluntarily pays at the input stage. Aca- demic papers become valuable when they are disseminated and cited. Removing barriers to information dissemination can facilitate research, enrich education, and provide a foundation for bringing humanity together in a shared inquiry into intellectual dialog and knowledge.

The journal Episodes does not charge any fees inevitably incurred in the open-access models. The Episodes falls in the category of Gratis Open Access journal (Suber, 2012). This represents a philosophy based on the concept of an academic community that has maintained the genuine principle of open access for decades. Therefore, it is clear that Episodes is a forward-looking journal responsive to contemporary demands and based on a sense of community.

\section{Gender Equality and Regional Distribution}

Since 1978, Episodes has been an international and interdisciplinary open-access and free publication that covers all geoscience disciplines. To further establish itself as a flagship journal in Earth science(s), Episodes needs to set more ambitious goals for gender equality.

To accelerate the realization of gender equality (Esquivel and Sweetman, 2016), Episodes should aim for an ambitious and realistic proportion of editors, continuously monitor and improve its gender equality status, and reflect the results to promote leadership. Currently, Episodes has over twice (44\%) as many female editorial members as other geoscience journals (18\%) (Fig. 1).

This indicator reflects one of the surest ways to change the earth

\section{Episodes}

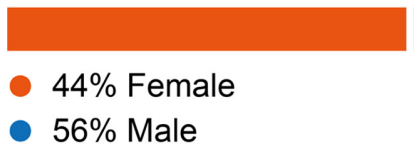

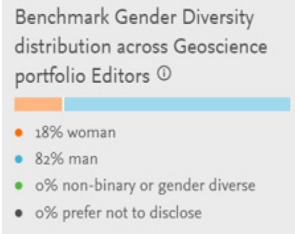

Figure 1. Gender diversity distribution of Episodes (left figure) and benchmark gender diversity distribution (right figure) across geoscience portfolio editors (adapted from Elsevier). 


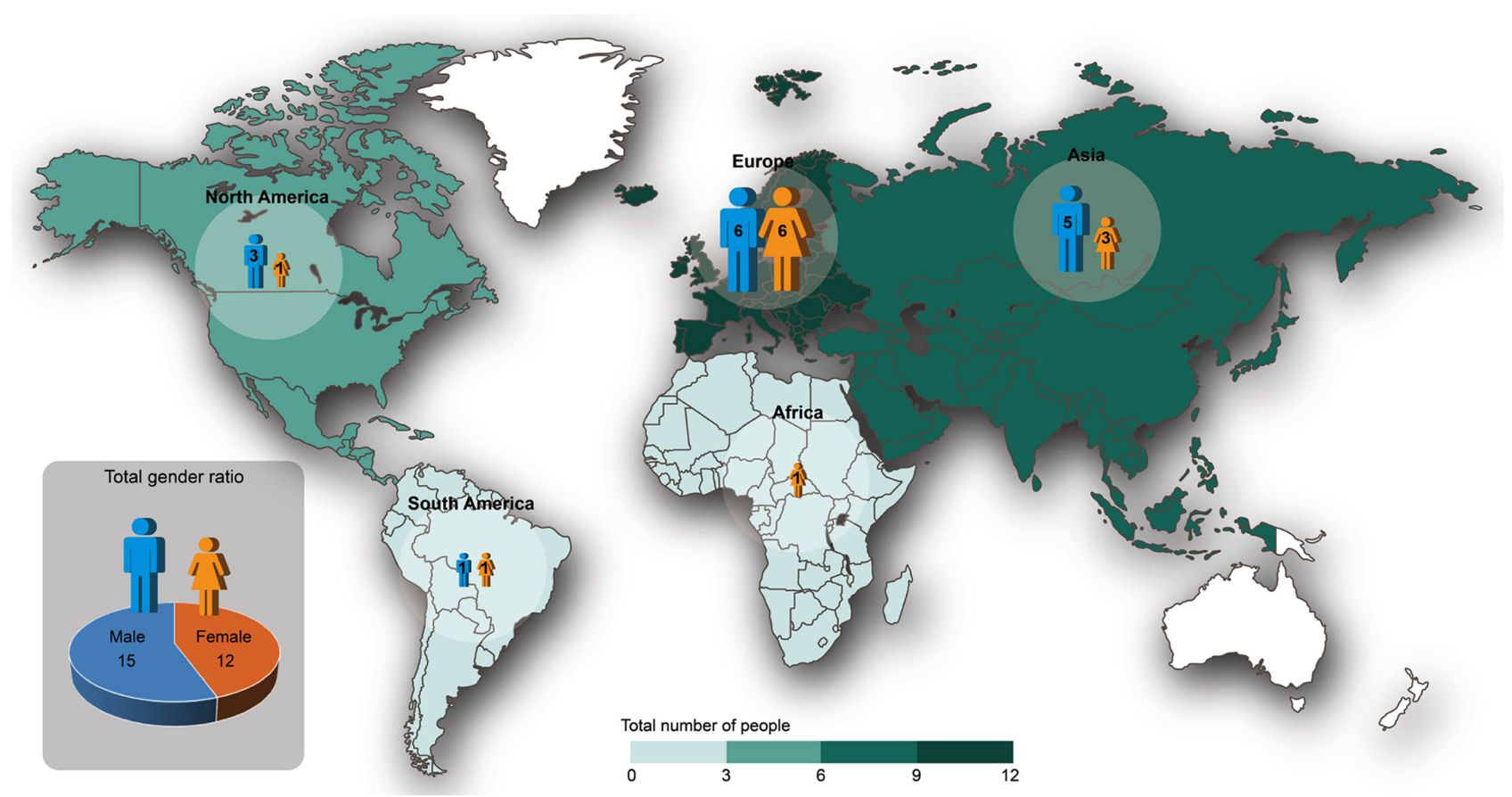

Figure 2. Regional and gender diversity distribution of Episodes editors.

science community in a more positive and fundamental direction for future scholars in earth science worldwide, providing useful information to other academic communities and meaningful data for diversity in the earth science community to further the empowerment of women. In addition to gender equality, regional balance is another unique value that our journal pursues (Fig. 2). Besides gender and geography diversity in the Editorial Board, Episodes seeks for equal distribution in reviewers and authors. With these actions, Episodes tries to meet the Sustainable Development Goal 5: Achieve gender equality (United Nations, https://sdgs.un.org/goals).

\section{References}

Budapest Open Access Initiative, 2002, https://www.budapestopenaccessinitiative.org/read [accessed 24th April, 2021].
Budapest Open Access Initiative, 2012, https://www.budapestopenaccessinitiative.org/boai-10-recommendations [accessed 24th April, 2021].

Elsevier, https://www.elsevier.com/connect/help-expand-a-public-datasetof-research-that-support-the-un-sdgs [accessed 24th April, 2021].

Esquivel, V., and Sweetman, C., 2016. Gender and the sustainable development goals. Gender and Development, v. 24, pp.1-8.

Suber, P., 2012, Open access. Cambridge, Mass: MIT Press, 1-242p. https:// dash.harvard.edu/bitstream/handle/1/10752204/9780262517638_Open_Access.pdf.

United Nations, https://sdgs.un.org/goals [accessed 24th April, 2021]. 